\title{
Learning science like a scientist
}

\author{
Successful science education requires a knowledgeable teacher, a challenging curriculum, and teaching methods that \\ actively engage students in a learning process that evokes the scientific method.
}

\begin{abstract}
$\mathrm{n}$ the latest international comparison of science knowledge among students, US high school seniors were ranked near the bottom (http:// www.ed.gov/inits/TIMSS/index.html). As we look for explanations, the results of the survey suggest that in other countries teachers are more qualified and topics are introduced earlier and taught in more depth. What happens in the United States when these underprepared students enter universities? All too often they are met with large, impersonal lecture halls that may do little to increase their knowledge of or enthusiasm for science. In order to inspire the next generation of scientists and ensure that the population is scientifically literate, scientific leaders and decisionmakers need to take a hard look at the 'who, what and how' of American science education.

Who is currently teaching science classes? Unfortunately, at the elementary school level very few teachers have a background in science, and even many high school science teachers do not hold a bachelor's degree in science. For example, 55\% of high school physics teachers have neither a major nor a minor in the subject (http://www.ed.gov/inits/TIMSS/index. $\mathrm{html}$ ). If you ask a graduate student contemplating a move from research to teaching, you will find that one significant impediment to becoming a high school science teacher is the length of time needed to acquire both a science degree and teaching credentials. Developing programs aimed at integrating science and education training, as well as increasing the ease of transitions from research to education, are achievable steps toward creating better-trained science teachers.
\end{abstract}

At the collegiate level, the challenges are quite different. The professors currently teaching the classes are clearly experts in their topics. However, as Thomas Cech, president of the Howard Hughes Medical Institute and Chemistry Nobel laureate, comments: "Why do today's university faculty so rarely apply the same innovation and energy to their teaching that they invest in their research? There is no mystery here. Good teaching may be appreciated, even applauded, but good research is at the heart of the reward structure" (Science 299, 165, 2003). Professors need to be given the time and resources for effective teaching, and then rewarded for their efforts.

Perhaps more challenging will be altering what is taught and how it is taught. In evaluating kindergarten through high school education, the American Association for the Advancement of Science (AAAS) publication 'Science for All Americans' (http://www.project2061.org/ publications/sfaa/) concludes that "the present science textbooks and method of instruction, far from helping, often actually impede progress toward science literacy. They emphasize the learning of answers more than the exploration of questions, memory at the expense of critical thought, bits and pieces of information instead of understandings in context, recitation over argument, reading in lieu of doing."

Currently, school science curriculums cover an extensive list of topics in a superficial manner, with significant repetition from year to year.
Included in the 'Science for All Americans' report are recommendations for instead focusing efforts on teaching students only the most fundamental skills and knowledge to facilitate learning at a deeper level. As part of this project, efforts are ongoing to develop a model curriculum for each grade level. An alternative approach to improving the level of conceptual science understanding is an integrated science curriculum, such as is being offered to undergraduates at Princeton University. In describing the curriculum, David Botstein, director of the Lewis-Sigler Institute for Integrative Genomics, emphasized that integrating teaching of the sciences can "convey a clearer picture both of the underlying principles and the diversity of their applications" (Science 303, 788-790, 2004).

Lectures, even the most entertaining ones, are not the most effective way to encourage conceptual understanding. Yet lectures are still the dominant mode of teaching. In high school and introductory college chemistry classes, teachers lecture to their students $90 \%$ of the time (Chem. Eng. News 84, 3, 2006). Supplementing or replacing lectures with more active learning approaches can seem daunting, particularly in large classrooms, but a number of alternative methods involving group interactions and inquiry-based learning approaches have been used successfully (Science 304, 521-522, 2004). Examples of non-lecture-based curriculum for teaching chemistry and biology include 'Process Oriented Guided Inquiry Learning' (POGIL) (http://www.pogil.org) and 'Integrated Biological Science Courses Organized around Research Experiences' (http://www. ibscore.org/courses.htm).

A number of organizations are working to develop and encourage the use of new approaches to science education at all levels. For example, the Howard Hughes Medical Institute (HHMI) funds colleges and individual professors to develop innovative ideas in teaching (http://www.hhmi.org/ grants/office/undergrad/). A common theme in many of these approaches is that the closer a classroom experience can come to the scientific method of laboratory research, the more successful the approach. Given this, scientists should be in a unique position to help develop effective teaching approaches. Emulating the HHMI model by using federal money to fund 'research projects' in science education would enable interested professors to devote more time to this critical university function.

The ills of the current system of science education in the United States are no secret, and in many cases potential solutions already exist. For real reform, a national push toward improving the quality and content of science education is necessary. With the 'American Competitiveness Initiative' proposed by President Bush (http://www.whitehouse.gov/ stateoftheunion/2006/aci/), and the possibility that funding improvements in science education could receive bipartisan support in the US Congress, there is the opportunity to make real changes in education. In addition to significant investment, what is needed is for scientists and scientific educators to become leading figures in initiatives designed to bring the best of science to science education. 